\title{
Germination test as a fast method to detect glyphosate-resistant sourgrass
}

\author{
Marcos Altomani Neves Dias ( ${ }^{*}$ ); Flavio Eduardo Botelhos Obara; Natalia Arruda; \\ Patricia Ribeiro Cursi; Navara Roberto Gonçalves; Pedro Jacob Christoffoleti
}

\author{
(USP), Escola Superior de Agricultura “Luiz de Queiroz” (ESALQ), Departamento de Produção Vegetal, \\ Avenida Pádua Dias, 11, 13418-900 Piracicaba (SP), Brasil. \\ $\left({ }^{*}\right)$ Corresponding author: marcosaltomani@gmail.com
}

Received: Mar. 2, 2015; Accepted: Apr. 18, 2015

\begin{abstract}
The occurrence of weed species with different levels of resistance to glyphosate has increasingly spread in agricultural areas. In Brazil, sourgrass is among the main species presenting issues in this regard. Thus, fast and reliable methods to detect glyphosate resistance are of special interest for this specie, either for research or rational management purposes. This study was carried out to verify the feasibility of using the germination test to detect glyphosate resistance in sourgrass. The experiment was conducted with two sourgrass biotypes, with different levels of susceptibility to glyphosate. The seeds were previously imbibed in solutions composed of $0,0.1875 \%, 0.25 \%, 0.75 \%, 1.5 \%, 3 \%$ and $6 \%$ of glyphosate during two periods, five and ten minutes, and submitted to germination tests. The results indicate the germination test as a feasible and time-saving approach to evaluate glyphosate-resistant sourgrass, with results available in seven days.
\end{abstract}

Key words: Digitaria insularis (L.), herbicide resistance, weed management, seed analysis.

Herbicide resistance is the inherited ability of a plant to survive and reproduce following exposure to a dose of herbicide normally lethal to the wild type. In plants, resistance may be naturally occurring or induced by such techniques as genetic engineering or selection of variants produced by tissue culture or mutagenesis (Green, 2014). Therefore, according to Christoffoleti \& Ovejero (2008), the weed resistance to an herbicide is characterized by the heritability of some biotypes, in a given population, to survive and reproduce after it is exposed to a lethal dose of the herbicide for normal individuals (susceptible) of that specie.

Glyphosate-based herbicides are extensively used worldwide, consisting in an efficacious and low-cost method to control a wide range of weed species. More recently, a considerable increase on glyphosate utilization occurred due to the large adoption of glyphosate-resistant crops by growers (Green, 2014).

The intensive use of glyphosate over wide areas has selected weed populations that are resistant to its mode of action (Moreira \& Christoffoleti, 2008; Green, 2014). Due to the enormous relevance of glyphosate to modern agriculture, efforts must be directed in order to promote a rational use of this herbicide (Soares et al., 2012).

Digitaria spp. is economically important for Brazilian agriculture, infesting a wide range of crops throughout the country (Mondo et al., 2010). The continuous application of glyphosate along the years has selected resistant biotypes of Digitaria insularis, firstly detected in 2009 (Villalba, 2009; Christoffoleti, 2009; Nicolai et al., 2010). A successful chemical management of weeds is based on correct herbicide recommendations. Thus, the detection of herbicide resistance is an important step towards determining the right herbicides for that specific field or region (Melo et al., 2012).

A common method to test weed resistance to a given herbicide is cultivating the plants in the field or greenhouse and submit them to different dosages of the herbicide, in order to determine the level of resistance of each population or biotype, as well as the effective dosage for controlling the weed population. This method provides reliable results; however, it is time-consuming, mainly due to the period required for plants growth (Correia et al., 2010).

Another ways to detect the resistance are through molecular testing such as ELISA (Enzyme Linked Immunosorbant Assay) protein analysis, and PCR (Polymerase Chain Reaction), which are based on DNA analysis (Miranda et al., 2006). These methods are efficient, but demands higher investments in equipment and personnel training.

Therewith, a fast, reliable and low-cost method would be very useful to evaluate glyphosate resistance in sourgrass. The detection of herbicide resistance through the germination test is already used by seed quality control 
programs in the seed industry, for crops such as soybean and corn, in order to assess the glyphosate resistance of each seed lot prior to commercial release (Cunha et al., 2005; Miranda et al., 2006; Heinz et al., 2011).

This study aimed to investigate the feasibility of using the germination test as a rapid and low-cost method to assess glyphosate-resistance in sougrass.

The experiment was carried out with two sourgrass seed lots, harvested at different locations. Seeds from the resistant biotype (lot R) were collected in Matão (SP),

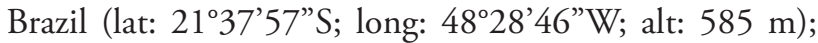
seeds from the susceptible biotype (lot $S$ ) were collected in Piracicaba, SP, Brazil (lat: 2242’30”S; long: $47^{\circ} 38^{\prime} 00^{\prime \prime} \mathrm{W}$; alt: $546 \mathrm{~m}$ ). Both seed lots were previously tested in order to confirm the glyphosate resistance and susceptibility, with plants cultivated in greenhouse and sprayed with glyphosate at 3-5 tiller growth stage (data not shown).

In order to use the germination test to detect the glyphosate resistance or susceptibility of both seed lots, the seeds were previously imbibed in solutions containing the herbicide, composed of $0,0.1875 \%, 0.375 \%, 0.75 \%, 1.5 \%, 3 \%$ and $6 \%$ of glyphosate.

For imbibition, the seeds were maintained for 5 or 10 minutes, depending on the treatment, among two sheets of blotting paper moistened with the glyphosate solutions, at a rate of 2.5 times the weight of the dry paper. Afterwards, seeds were promptly submitted to germination test.

The germination test was conducted with four replications of a hundred seeds, previously selected under magnifying glass, in plastic boxes $(11.5 \times 11.5 \times 3.5 \mathrm{~cm})$ containing two sheets of filter paper watered at a rate of 2.5 times the weight of the dry substrate. The boxes were placed in a germination chamber, at alternate temperatures of $20-35^{\circ} \mathrm{C}$, with 8 hours photoperiod (Brasil, 2009). The counting occurred at the $7^{\text {th }}$ and $14^{\text {th }}$ days after sowing, with results expressed in percentages of normal seedlings (Brasil, 2009).

Results of final germination percentage, based on a scale from 0 (maximum germination) to $100 \%$ (minimum germination), were first submitted to an analysis of variance ( $\mathrm{F}$ test, $\mathrm{p}<0.05)$. Afterwards, a non-linear regression analysis of log-logistic type was applied, using drc package (Ritz \& Streibig, 2005) of R software (R Foundation for Statistical Computing, 2012), according to the model proposed by Streibig (1988), where: $y$ is the control percentage; $x$ is the herbicide dosage (\%); $a$ is the amplitude between the maximum and minimum values of the variable; $b$ corresponds to the dose required to reach $50 \%$ of control; $c$ is the curve declivity.

$y=\frac{a}{\left[1+\left(\frac{x}{b}\right)^{c}\right]}$

According to Christoffoleti \& Ovejero (2004), the parameter $b$ corresponds to $\mathrm{C}_{50}$, which is the dosage that provides $50 \%$ of germination percentage. In addition, the $\mathrm{C}_{80}$ was also calculated.
The log-logistic analysis of sourgrass germination with glyphosate confirmed the differences among lots $\mathrm{R}$ and $\mathrm{S}$ (Figure 1), previously verified under greenhouse conditions (data not shown). According to Campos et al. (2009), the extremes values of control (maximum and minimum) are used in the log-logistic analysis when plants are sprayed with the herbicide in the field or pots, thus representing the maximum and minimum plant survival. In this study, the values of maximum and minimum germination were used for the same purpose, as shown in figure 1.

Despite the Brazilian Rules For Seed Testing (Brasil, 2009) suggests the final germination counting for Digitaria spp. on the $14^{\text {th }}$ day, the authors of this study verified that germination percentages did not substantially change after the $7^{\text {th }}$ day. Therewith, considering the demand for a time-saving method to detect glyphosate-resistance in this specie, the data provided by the $7^{\text {th }}$ day counting was also analyzed by the log-logistic model, in order to make a comparison with the results of $14^{\text {th }}$ day count.

Figure 1 contains the results of 5 and 10 minutes imbibition in the glyphosate solutions, followed by germination counting at the $7^{\text {th }}$ and $14^{\text {th }}$ days after sowing. It is possible to observe that, to a certain extent, 10-minutes imbibition resulted on higher control percentages of the resistant seed lot than 5-minutes imbibition. That probably occurred due to a phytotoxic effect associated to longer periods of imbibition in glyphosate solutions. However, despite the lower germination percentage verified with 10 -minutes imbibition treatment for lot $\mathrm{R}$, both periods of imbibition were capable to differentiate the biotypes as susceptible and resistant to glyphosate, with 5-minutes imbibition showing better results.

The results provided by 7 and 14-day germination counts showed high similarity for both seed lots and imbibition periods tested, thus indicating that 7-day results are reliable to indicate the level of resistance.

An effective method to assess the resistance of a given population to an herbicide is by calculating the resistance factor (RF) (Campos et al., 2009). According to Christoffoleti (2002), the RF represents the proportion between the dose required to control $50 \%$ of the resistant population and the dose required to control $50 \%$ of the susceptible population. RF values higher than 1 indicate an increase in the resistance level. In this study, the RF results ranged from 3.38 to 7.37 , showing an efficiency of all methods tested (5 and 10 minutes, $7^{\text {th }}$ and $14^{\text {th }}$ days) to asses glyphosate-resistance in sourgrass.

Table 1 contains the percentage of glyphosate in the solution required to control $50 \%$ and $80 \%\left(\mathrm{C}_{50}\right.$ and $\left.\mathrm{C}_{80}\right)$ of both sourgrass biotypes. It is possible to observe similarity among treatments for both levels of control, $\mathrm{C}_{50}$ and $\mathrm{C}_{80}$. The $\mathrm{C}_{80}$ is adopted as the minimum percentage of control required for herbicides registration in Brazil (Campos et al., 2009). 

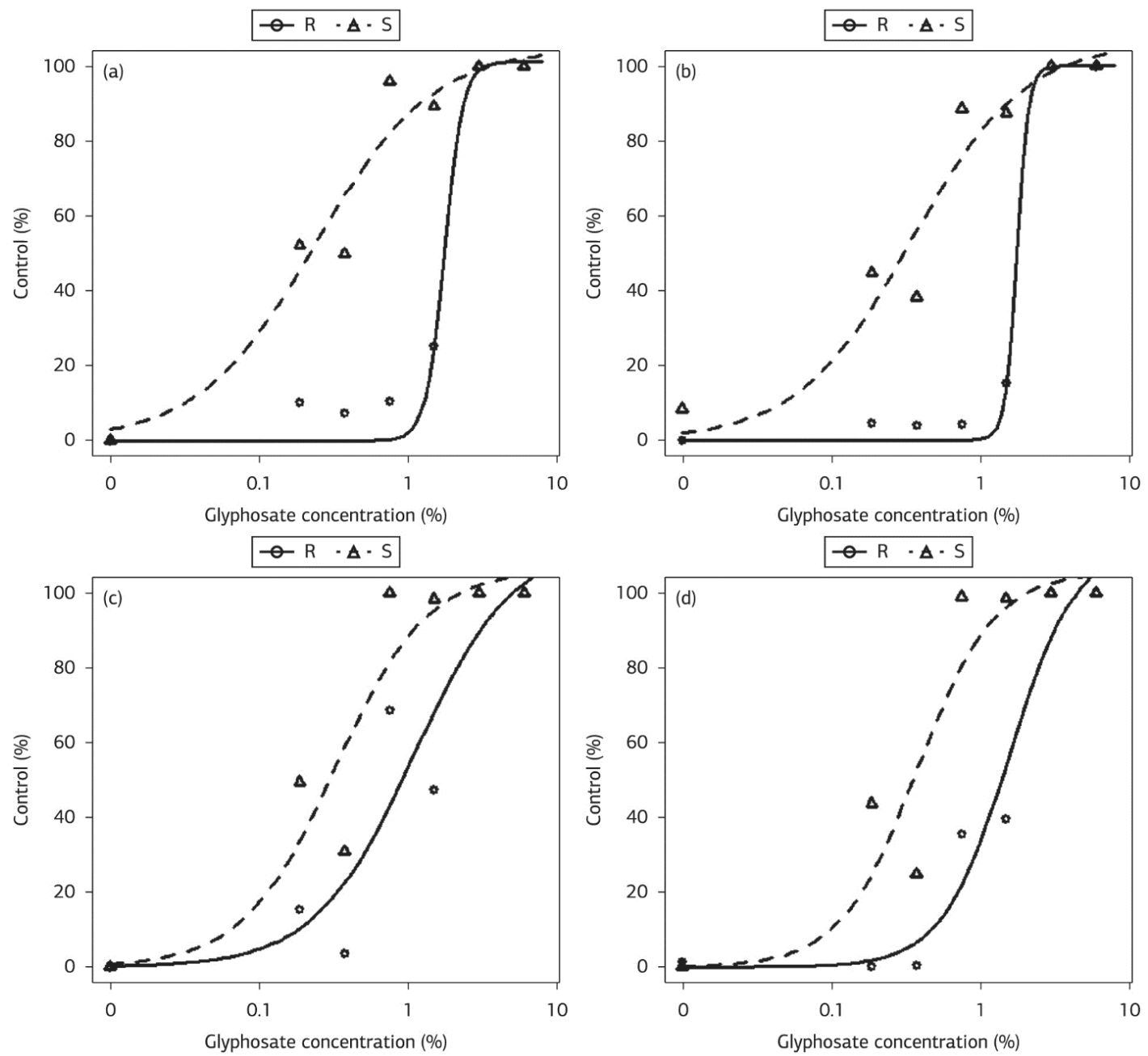

Figure 1. Final germination percentage (Control, \%) of two sougrass biotypes, resistant (R) and susceptible (S) to glyphosate, after seed imbibition in solutions containing different concentrations of glyphosate. (a): 5 minutes imbibition, 7-day of germination; (b): 5 minutes imbibition, 14 days of germination; (c): 10 minutes imbibition, 7 days of germination; (d): 10 minutes imbibition, 14 days of germination. $0 \%$ of control corresponds to the maximum germination pergentage obtained in each treatment.

Table 1. Solution concentration required to control $50 \%$ and $80 \%\left(\mathrm{C}_{50}\right.$ and $\left.\mathrm{C}_{80}\right)$ of two sourgrass biotypes, resistant $(\mathrm{R})$ and susceptible (S) to glyphosate, after seed imbibition in solutions containing glyphosate, for 5 and 10 minutes, with germination counting at the $7^{\text {th }}$ and $14^{\text {th }}$ days after sowing. RF represents the resistance factor of each treatment, considering $50 \%$ of control $\left(\mathrm{C}_{50}\right)$

\begin{tabular}{ccccc} 
& \multicolumn{2}{c}{$\mathbf{5}$ minutes } & \multicolumn{2}{c}{$\mathbf{1 0}$ minutes } \\
\cline { 2 - 5 } Control & $\mathbf{7}$ days & $\mathbf{1 4}$ days & $\mathbf{7}$ days & $\mathbf{1 4}$ days \\
$\mathrm{S}\left(\mathrm{C}_{50}\right)$ & 0.24 & 0.34 & 0.32 & 0.38 \\
$\mathrm{R}\left(\mathrm{C}_{50}\right)$ & 1.76 & 1.76 & 1.10 & 1.58 \\
$\mathrm{~S}\left(\mathrm{C}_{80}\right)$ & 0.83 & 1.15 & 0.86 & 0.87 \\
$\mathrm{R}\left(\mathrm{C}_{80}\right)$ & 2.14 & 1.99 & 3.22 & 3.19 \\
$\mathrm{RF}\left(\mathrm{C}_{50}\right)$ & 7.37 & 5.11 & 3.39 & 4.16 \\
\hline
\end{tabular}

Therewith, the germination test is efficient to calculate the $\mathrm{C}_{50}$ and $\mathrm{C}_{80}$, providing uniform results.

Thus, the germination test showed to be a feasible and time-saving approach to detect glyphosate-resistant sourgrass. The same approach can also be tested for other weed species and herbicides. Considering the high relevance of glyphosate-resistant sourgrass for Brazilian agriculture, this approach can be very useful to rapidly detect resistant biotypes, allowing faster decisions in terms of weed management in the area or region.

The germination test is a feasible and time-saving approach to detect glyphosate-resistant sourgrass, with results available in seven days.

\section{REFERENCES}

Brasil. Ministério da Agricultura, Pecuária e Abastecimento - MAPA. Secretaria de Defesa Agropecuária. (2009). Regras para análise de sementes. Brasília: ACS.

Campos, L. H. F., Francisco, M. O., Carvalho, S. J. P., Nicolai, M., \& Christoffoleti, P. J. (2009). Suscetibilidade de Ipomoea quamoclit, 
I. triloba e Merremia cissoides aos herbicidas sulfentrazone e amicarbazone. Planta Daninha, 27, 831-840. http://dx.doi.org/10.1590/S010083582009000400022 .

Christoffoleti, P. J. (2002). Curvas de dose-resposta de biótipos resistente e suscetível de Bidens pilosa L. aos herbicidas inibidores da ALS. Scientia Agricola, 59, 513-519. http://dx.doi.org/10.1590/ S0103-90162002000300016.

Christoffoleti, P. J. (2009). A experiência dos cultivos transgênicos resistentes ao glifosate e seu impacto na agricultura brasileira. Serie Actas INIA, 44, 27-35.

Christoffoleti, P. J., \& Ovejero, R. F. L. (2004). Definiçóes e situação da resistência de plantas daninhas aos herbicidas no Brasil e no mundo. In P. J. Christoffoleti (Coord.), Aspectos de resistência de plantas daninhas a herbicidas (p. 3-22). Londrina: Associação Brasileira de Ação a Resistência de Plantas aos Herbicidas (HRAC-BR).

Christoffoleti, P. J., \& Ovejero, R. F. L. (2008). Resistência das plantas daninhas a herbicidas: definiçóes, bases e situação no Brasil e no mundo. In P. J. Christoffoleti (Coord.), Aspectos da resistência de plantas daninhas a herbicidas (3. ed., p. 9-34). Piracicaba: Associaçáo Brasileira de Ação a Resistência de Plantas aos Herbicidas - HRAC-BR.

Correia, N. M., Leite, G. J., \& Garcia, L. D. (2010). Resposta de diferentes populações de Digitaria insularis ao herbicida glifosato. Planta Daninha, 28, 769-776. http://dx.doi.org/10.1590/S010083582010000400009 .

Cunha, C. S. M., Tillmann, M. A. A., Villela, F. A., Dode, L. B., \& Balerini, F. (2005). Comparação de métodos na detecção de sementes de soja geneticamente modificadas resistente ao glifosato. Revista Brasileira de Sementes, 27, 167-175. http://dx.doi.org/10.1590/ S0101-31222005000100021.

Green, J. M. (2014). Current state of herbicides in herbicide-resistant crops. Pest Management Science, 70, 1351-1357. http://dx.doi. org/10.1002/ps.3727. PMid:24446395.

Heinz, R., Viegas No, A. L., \& Valente, T. O. (2011). Detecção de sementes de soja geneticamente modificadas por meio de teste de germinaçáo. Revista Agrarian, 4, 20-26.
Melo, M. S. C., Rosa, L. E., Brunharo, C. A. D. C. G., Nicolai, M., \& Christoffoleti, P. J. (2012). Alternativas para o controle químico de capim-amargoso (Digitaria insularis) resistente ao glyphosate. Revista Brasileira de Herbicidas, 11, 195-203. http://dx.doi.org/10.7824/ rbh.v11i2.145.

Miranda, D. M., Tillmann, M. Â. A., Noldin, J. A., \& Balerini, F. (2006). Bioensaio em casa-de-vegetação na detecção e quantificação de sementes de soja geneticamente modificada. Revista Brasileira de Sementes, 28, 187-192. http://dx.doi.org/10.1590/S010131222006000100026 .

Mondo, V. H. V., Carvalho, S. J. P., Dias, A. C. R., \& Marcos, J., Fo. (2010). Efeitos da luz e temperatura na germinação de quatro espécies de plantas daninhas do gênero Digitaria. Revista Brasileira de Sementes, 32, 131-137. http://dx.doi.org/10.1590/S0101-31222010000100015.

Moreira, M. S., \& Christoffoleti, P. J. (2008). Resistência das plantas daninhas aos herbicidas inibidores da EPSPs. In P. J. Christoffoleti (Coord.), Aspectos da resistência de plantas daninhas a herbicidas (3. ed.). Piracicaba: Associação Brasileira de Ação a Resistência de Plantas aos Herbicidas - HRAC-BR.

Nicolai, M., Carvalho, S. J. P., Christoffoleti, P. J., \& Correa, R. A. L. (2010). Programas de manejo químico de plantas daninhas em plantio de cana-de-açúcar fundamentados em duas aplicaçóes de herbicidas. Revista Agrogeoambiental, 2, 135-144.

R Foundation for Statistical Computing. (2012) R: a language and environment for statistical computing. Vienna.

Ritz, C., \& Streibig, J. C. (2005). Bioassay analysis using R. Journal of Statistical Software, 12, 5.

Soares, D. J., Oliveira, W. S., Ovejero, R. F. L., \& Christoffoleti, P. J. (2012). Control of glyphosate resistant Hairy Fleabane (Conyza bonariensis) with Dicamba and 2,4D. Planta Daninha, 30, 401-406. http://dx.doi.org/10.1590/S0100-83582012000200020.

Streibig, J. C. (1988). Herbicide bioassay. Weed Resistance, 28, 479-484. http://dx.doi.org/10.1111/j.1365-3180.1988.tb00831.x.

Villalba, A. (2009). Resistência a herbicidas: Glifosato. Ciencia, Docencia y Technologia, 39, 169-186. 